\title{
A PRODUÇÃO ACADÊMICA JURÍDICA SOBRE AS AÇÕES AFIRMATIVAS NO BRASIL (2013 A 2016): TESES E DISSERTAÇÕES SOB A ÓTICA DOS DIREITOS HUMANOS E FUNDAMENTAIS
}

\author{
THE LEGAL ACADEMIC PRODUCTION ON AFFIRMATIVE ACTIONS IN BRAZIL \\ (2013 TO 2016): THESES AND DISSERTATIONS FROM THE STANDPOINT OF HUMAN \\ AND FUNDAMENTAL RIGHTS
}

\begin{abstract}
Richard Pae Kim
Doutor e Mestre em Direito pela USP. Pós-doutorado em políticas públicas pela UNICAMP. Professor dos Cursos de Graduação e de Mestrado em Direito da UNIMEPSP. Professor dos cursos de pós-graduação da Escola Paulista da Magistratura. Juiz de Direito/SP. Juiz Auxiliar de Gabinete no Supremo Tribunal Federal.

E-mail: rppk@uol.com.br
\end{abstract}

Flávia Carneiro Tommasiello

Advogada e Mestranda em Direito na UNIMEP. E-mail: flaviatommasiello@gmail.com

Recebido em: 10/12/2017

Aprovado em: 22/04/2018

\begin{abstract}
RESUMO: O presente trabalho é resultado de pesquisa consistente em levantamento da produção científica na área do Direito das Teses e Dissertações defendidas nas universidades brasileiras no período de 2013 a 2016, que tenham como pano de fundo - principal ou parcial - o tema das ações afirmativas. A metodologia utilizada na pesquisa foi a do "estado do conhecimento", com a finalidade de mapear e levantar dados sobre o conhecimento produzido sobre esse novel tema em um universo específico. A opção pela análise dasTeses e Dissertações desse período justifica-se porque os trabalhose resumosencontram-se disponíveis no Banco de Teses da Coordenação de Aperfeiçoamento de Pessoal de Nível Superior - CAPES. A importância das ações afirmativas, como instrumentos de promoção da igualdade material ou substancial direcionados para algumas minorias sociais, em razão de exclusões históricas, se reflete não só pela produção acadêmica, mas também pelasatuais políticas públicas que têm sido amplificadas em todos os níveis federativos.A constitucionalidade de normas que criaram algumas dessas políticas de discriminação positivafoi reconhecida inclusive pelo Supremo Tribunal Federal, que as considerou como reais e necessárias medidas a serem adotadas a fim de amenizaros déficits de cidadania ou remediar as condições sociais resultantes de uma herança histórica discriminatória. Nesse trabalho mencionaremos um esboço do conteúdo jurídico das ações afirmativas e suas políticas, quais foram os principais temas tratados na referida produção científico-jurídica, a sua divisão por regiões e uma singela análise do "estado do conhecimento".
\end{abstract}

Palavras-chave: Direitos Fundamentais. Igualdade. Ações Afirmativas.Políticas Públicas. Produção Acadêmica. Estado do Conhecimento.

ABSTRACT: The present paper is the result of a research that consists on a survey of the scientific production of Theses and Dissertations in Brazilian Law Schools from 2013 to 2016, having as background - main or partial - the theme of affirmative actions. The methodology used

Revista de Direito Brasileira | São Paulo, SP | v. 19 | n. 8 | p. 276 - 297 |Jan./Abr. 2018 
in the research was the "state of knowledge", with the purpose of mapping and collecting data about the knowledge produced on this novel theme in a specific group. The option to analyze the Theses and Dissertations of this period is justified because the papers and abstracts are available in the Thesis Database of the Coordination of Improvement of Higher Education Personnel CAPES. The importance of affirmative actions, as instruments of promotion of substantial equality directed to some groups of social minorities, victims of historical exclusions, is reflected not only by the academic production, but also by the current public policies that have been amplified at all Federative levels. The constitutionality of norms that created some of these positive discrimination policies was recognized even by the Brazilian's Supreme Court, which considered them as real and necessary measures to be adopted in order to alleviate the deficits of citizenship or to remedy the social conditions, result of a discriminatory historical inheritance. In this paper we will mention an outline of the legal content of affirmative actions and their policies, which were the main topics covered in this scientific-legal production, it's division by our country regions and a simple analysis of the "state of knowledge."

Keywords: Fundamental Rights. Equality. Affirmative Actions. Public Policy. Academic Production. State of Knowledge.

SUMÁRIO: Introdução; 1. Direitos humanos, direitos fundamentais e as funções do Estado na sua relação com a sociedade; 2. Igualdade e a questão da discriminação positiva; 3. Ações afirmativas e os contornos das políticas públicas no Brasil; 4. O caminho da pesquisa e os resultados; 5. Análise dos resultados e algumas lacunas; Considerações finais; Referências Bibliográficas.

\section{INTRODUÇÃO}

Conhecer o conteúdo do que a academia está a pesquisar e produzir sobre as ações afirmativas se faz necessário, uma vez que os resultados das pesquisas podem indicar lacunas e necessidade de mudanças políticas e normativas de inclusão por meio de políticas de discriminação positiva. Oaprofundamento de determinadas questões pela academia, em especial, quando impactam na vida das pessoas e na história de uma nação importa num imperativo constante e um dever de nossas universidades. Apesar da problemática das desigualdadesencontrar-se arraigada em nossa história, entender adequadamente e de forma consciente as ações afirmativas possibilitará que as instituições e a sociedade questionem o passado, efetivem o presente e planejemum futuro mais justo.

A metodologia utilizada, do "estado do conhecimento", possibilita uma visão geral do que vem sendo produzido sobre o tema no âmbito da pós-graduação stricto sensu, na área do Direito, a possibilitara todos os interessados que se perceba não só a evolução das pesquisas, mas, principalmente, identificar as lacunas existentes no campo teórico e prático a viabilizar futuras e acertadas mudanças não só no campo da pesquisa, mas também das ações públicoadministrativas.

Esse trabalho não pretende esgotar a análise dessas produções, mas tem a pretensão de tratar, de forma breve e pontual, aspectos do material levantado sobre o surgimento, evolução e constitucionalização dos direitos fundamentais, o conteúdo jurídico das ações afirmativas no Brasil, as perspectivas de mudanças e, em especial, apontar os temas que, tendo como pano de fundo as ações afirmativas - total ou parcialmente -, deixaram de ser objeto das pesquisas e, consequentemente, daspropostas acadêmicas.

Do levantamento e análise dos trabalhos na área do Direito- em nível de Doutorado e de Mestrado -pudemos delimitar a distribuição da produção por região no Brasil, as principais temáticas desenvolvidas e seus desdobramentos, alguns paradoxos conceituais e, por fim, 
sentimos a ausência de alguns temas que pensamos ser importantes para as mudanças positivas em nosso país plural.

Para entenderemos melhor a necessidade de ações afirmativas e utilizarmos as principais premissas que serão necessárias para as nossas conclusões, faz-se adequadorememorarmos alguns fundamentos das ações afirmativas, quais sejam: os direitos humanos, direitos fundamentais, as funções do Estado em relação à sociedade, as restrições aos direitos e seus limites,oDireito como elemento de justiça,o conteúdo jurídico da igualdade e os pressupostos de validade das discriminações positivas. Vejamos.

\section{DIREITOS HUMANOS, DIREITOS FUNDAMENTAIS E AS FUNÇÕES DO ESTADO NA SUA RELAÇÃO COM A SOCIEDADE}

Embora os "direitos humanos" sejam considerados universais para todos os povos e em todos os tempos, sob uma dimensão não só jusnaturalista, mas também sob a perspectiva de uma normativa internacional, a doutrina tem sedimentado o entendimento no sentido de que os "direitos fundamentais" são aqueles, institucionalmente e juridicamente garantidos, com limitação no espaço e no tempo ${ }^{1}$ em uma nação. Aliás, a ordem mencionada por J.J. Gomes Canotilho não se restringe à Constituição, pois ele diferencia os "direitos fundamentais formalmente constitucionais" - enunciados por normas com valor constitucional formal - dos "materialmente fundamentais" - direitos constantes das leis aplicáveis de direito internacional não positivados constitucionalmente ${ }^{2}$.

Conforme escólio de Gilmar Mendes e Paulo Branco ${ }^{3}$, “a expressão direitos humanos, ou direitos do homem, é reservada para aquelas reinvindicações de perene respeito a certas posições essenciais ao homem. São direitos postulados em bases jusnaturalistas, contam com índole filosófica e não possuem como característica básica a positivação num ordem jurídica particular", mas que por conta de sua vocação universalista supranacional, ainda designa pretensões de respeito à pessoa humana, inseridas em documentos de direito internacional.

Droits fondamentaux, expressão que restou cunhada na França de 1770 - em meio ao movimento político e cultural que culminou na Declaração dos Direitos do Homem e do Cidadão de 1789, mas que também formatou a primeira Constituição francesa de 1791 -evoluiu nos últimos séculos para abarcar não só os direitos individuais, mas também os direitos sociais, econômicos e de solidariedade.

Os novos enfoques, espécies, gerações ou dimensões, conforme expressões doutrinárias a serem adotadas pelo leitor e estudioso do Direito, trouxeram um novo pensar sobre algumas questões, que vão desde a titularidade desses direitos fundamentais - sob o aspecto subjetivo do beneficiário do direito/norma, a sua eficácia jurídica e fática e, por fim, que buscam definir os limites ou restrições passíveis de serem impostas pelo ordenamento jurídico.

Norberto Bobbio chegou a apontar quatro dificuldades para a busca dos fundamentos absolutos dos direitos fundamentais ${ }^{4}$ : a) a primeira, no sentido de que a expressão "direitos do homem" possui conteúdos difíceis de se definir, porquanto desprovida de conteúdos objetivos e, quando esta é estabelecida, traz uma diversidade de possibilidades interpretativas, dependendo das posições ideológicas dos intérpretes e dos valores que permeiam as inúmeras situações; b) a segunda dificuldade consiste na constante mutação histórica e axiológica dos direitos

\footnotetext{
${ }^{1}$ CANOTILHO, J.J. Gomes. Direito Constitucional e Teoria da Constituição. Coimbra: Almedina, 2002.

${ }^{2}$ Também nesse sentido, o escólio de COMPARATO, Fábio Konder. A afirmação histórica dos direitos humanos. São Paulo: Saraiva, 2001, p.56.

${ }^{3}$ MENDES, Gilmar; BRANCO, Paulo Gustavo Gonet. Curso de Direito Constitucional. São Paulo: Saraiva, 2013, p. 147.

${ }^{4}$ BOBBIO, Norberto. A era dos direitos. Rio de Janeiro: Campus, 1992, p.20.

Revista de Direito Brasileira | São Paulo, SP | v. 19 | n. 8 | p. 276 - 297 |Jan./Abr. 2018
} 
fundamentais, de acordo com as necessidades e interesses na sociedade dentro de um contexto temporal e situacional; c) a terceira dificuldade está em se obter um fundamento absoluto para os direitos fundamentais, diante não só da heterogeneidade, mas também porque podem ser conflitantes entre si; d) a quarta e última dificuldade consiste na percepção de que existem alguns direitos fundamentais que configuram liberdades, que exigem muitas vezes do próprio Estado uma obrigação negativa, em antinomia a outros, que consistem no exercício de poderes estatais, que necessitam de uma atitude positiva para a busca de sua efetividade: e, portanto, torna muito difícil de se inferir pela existência de um fundamento político-jurídico absoluto que seja idêntico para todas as espécies, não havendo como construir um liame entre direitos antagônicos, pois, segundo Bobbio, "quanto mais aumentam os poderes dos indivíduos, tanto mais diminuem as liberdades dos mesmos indivíduos".

Os direitos de primeira dimensão, "direitos-liberdades", como salientado por Jean Rivero $^{6}$, trazem no seu conteúdo essencial o aspecto negativo, dirigidos a uma abstenção estatal quanto ao exercício das liberdades individuais, coletivos e sociais. É claro que isto não implica na obstrução ao exercício do poder de polícia da Administração Pública, ou na possibilidade de uma normatização legislativa ou mesmo na regulação administrativa, mormente quando há o respeito aos direitos fundamentais na busca de uma ordem comum, um bem estar da coletividade. $\mathrm{O}$ que se impede é que a ação do Estado venha a violar os conteúdos mínimos e essenciais dos direitos fundamentais do indivíduo.

Os direitos da segunda dimensão são os sociais, culturais e econômicos, decorrentes do princípio da igualdade não só formal, mas em especial, material, visando o alcance da igualdade stricto sensu e surgiram, de fato, nos locais onde restou implantado o Estado Social. São direitos que exigem determinadas prestações por parte do Estado, impondo obrigações de fazer, de facere, que hoje tem sido objeto de intensa produção científica sobre o seu conteúdo jurídico e sobre os graus de efetividade e/ou de aplicabilidade das normas que visam garanti-las.

Conforme raciocínio de Norberto Bobbio, os direitos de liberdade são os que devem ser garantidos "através" ou "por meio" do Estado. É fato que os direitos fundamentais de segunda dimensão acabaram por passar por um "ciclo de baixa normatividade", como já salientado por autores como Paulo Bonavides, ou tiveram eficácia duvidosa, eis que, diante de sua própria natureza de direitos a prestações materiais, nem sempre foram considerados resgatáveis pela sua baixa concretude, pela carência de recursos ou, ainda, pela limitação essencial de vontade política.

Sob o manto da fraternidade, passou a doutrina a considerar a existência de direitos fundamentais de terceira dimensão, muitos consistentes nos chamados direitos difusos e coletivos, transindividuais, os quais tem como objeto a proteção do ser humano, e não apenas de determinado indivíduo ou do Estado em favor da coletividade. Na lição de Ingo Wolfgang Sarlet, lembrando o próprio Kant, há que se respeitar "o caráter intersubjetivo e relacional da dignidade da pessoa humana, sublinhando inclusive a existência de um dever de respeito no âmbito da comunidade dos seres humanos",7.

Aliás, a atribuição da denominação de "direitos de solidariedade" ou de "fraternidade" aos direitos da terceira dimensão é a consequência da sua implicação universal, como é o caso do direito a um meio ambiente sustentável e equilibrado, na medida em que, como lembra Ingo Wolfgang Sarlet, "sempre haverá como sustentar a dignidade da própria vida de um modo geral, ainda mais numa época em que o reconhecimento da proteção do meio ambiente como valor fundamental indicia que não mais está em causa apenas a vida humana, mas a preservação de todos os recursos naturais, incluindo todas as formas de vida existente no planeta, ainda que se

\footnotetext{
${ }^{5}$ Op. cit. p. 21.

${ }^{6}$ RIVERO, Jean \& MOUTOUH HUGUES. Liberdades Públicas I. São Paulo: Martins Fontes, 2009.

${ }^{7}$ SARLET, Ingo Wolfgang. Dignidade da pessoa humana e direitos fundamentais. Porto Alegre: Livraria do Advogado, 2008, p. 55.
} 
possa argumentar tal proteção da vida em geral constitua, em última análise, exigência da vida humana",

Parte da doutrina identifica ainda cinco espécies de direitos como sendo de terceira geração ou dimensão, quais sejam: o direito ao desenvolvimento, à paz, ao meio ambiente, à propriedade sobre o patrimônio comum da humanidade e o de comunicação. Entretanto, cuida-se de senso comum o entendimento de que este rol deve ser estendido na medida em que os processos de universalização forem se desenvolvendo e de globalização fundado em normas insculpidas em tratados e acordos internacionais.

Alguns autores, como Paulo Bonavides, vem admitido ainda a existência de direitos fundamentais de quarta geração, em decorrência da expansão da globalização econômica neoliberal, cuja filosofia de poder é negativa e que busca com mais intensidade a dissolução dos Estados nacionais e a redução dos fundamentos do conceito de soberania, como seriam os chamados direitos à democracia, à informação e ao pluralismo. Embora não aceito pelos doutrinadores de forma pacífica, lembra Paulo Bonavides que os direitos de quarta geração "compendiam o futuro da cidadania e o porvir da liberdade de todos os povos. Tão somente com eles será legítima e possível a globalização política"". Ressalte-se que, para o autor, esses direitos de quarta dimensão, como é o caso do direito à democracia, ao pluralismo e à informação, estariam consagrados no Preâmbulo, no Título I (Dos Princípios Fundamentais) e no Título II (Dos Direitos e Garantias Fundamentais) da Constituição Federal de 1988.

Necessário acentuar que as liberdades públicas adquiriram configuração mais complexa do que aquelas dos séculos XVII e XVIII que, inclusive, inspiraram a Revolução Francesa, e a evolução das liberdades decorreu do respeito à necessidade de enfrentar novas ameaças e desafios postos a partir do século XIX. Essa transmudação ampliativa não só adveio da modificação do conceito de Estado e do seu papel, como também da relação entre o indivíduo e aquele. Isso não quer dizer que os direitos clássicos tenham desaparecido. Perderam estes apenas o seu caráter limitado vinculado às liberdades e à igualdade e alcançaram outros direitos, além de se verem limitados à obrigatória compatibilização com outros princípios constitucionais.

A passagem do individualismo exacerbado para o reconhecimento da existência de direitos de alguns grupos sociais, em especial, após as manifestações que resultaram na elaboração de constituições republicanas, ficou mais evidente com a Declaração Universal dos Direitos do Homem de 1948, que tratou de quatro ordens de direitos individuais: direitos pessoais do indivíduo, direitos do indivíduo em face das coletividades, liberdades públicas e direitos públicos, e os direitos econômicos e sociais, estes decorrentes do amadurecimento de novos valores e de exigências ligadas ao bem-estar por meio do Estado.

Esse novo olhar para os direitos fundamentais - clássicos e novos - exigiu da doutrina a elaboração de novas classificações e teorias relacionais, dentre elas, a teoria dos quatro status de Georg Jellinek $^{10}$, que pode ser resumido da seguinte maneira: a) o status passivo é aquele em que o indivíduo encontra-se em posição de subordinação com relação aos poderes públicos, razão pela qual o Estado tem competência para vincular o indivíduo por meio de mandamentos e proibições; b) o status ativo representa o poder do indivíduo de interferir na formação da vontade do Estado, o que se dá, em regra, pelo exercício dos direitos políticos concretizados não só pelo voto, mas também por outros instrumentos de participação de direta (por exemplo, o referendo e o plebiscito); c) o status negativo representa o espaço que o indivíduo possui para agir de forma

\footnotetext{
${ }^{8}$ Op. cit., p. 35.

${ }^{9}$ BONAVIDES, Paulo. Curso de direito constitucional. São Paulo: Malheiros, 2008, p. 530 e segs.Há autores que se referem a essa categoria, mas ainda não há consenso na doutrina sobre qual o conteúdo desse tipo de direitos. Há quem diga tratarem-se dos direitos de engenharia genética, enquanto outros se referem à luta pela participação democrática. Por isso mesmo, mostra-se discutível a importância dessa categoria, como já salientado por Sérgio Resende de Barros.

${ }^{10}$ JELLINEK, Georg. Teoría General Del Estado. México: Fondo de Cultura Econômica, 2000.
} Revista de Direito Brasileira | São Paulo, SP | v. 19 | n. 8 | p. 276 - 297 |Jan./Abr. 2018 
livre, sem que ocorra a interferência estatal, ou seja, de se autodeterminar sem qualquer ingerência estatal; d) e, por fim, o status positivo, que consiste na possibilidade de o indivíduo exigir atuações positivas do Estado em seu favor, como ocorre, por exemplo, nos direitos econômicos e sociais que só podem ser exercidos com a implantação de políticas públicas específicas.

Levando-se em consideração essa classificação, pensamos que ainda permanecem latentes importantes questionamentos que devem ser respondidos pela academia e que pensamos ainda não foram suficientemente tratadosem nosso país, pois se referem à natureza dos direitos garantidos pelas ações afirmativas e a natureza da própria ação afirmativa. Eis algumas perguntas que ainda estão a aguardar respostas mais contundentes: a) Há um direito fundamental às ações afirmativas ou são derivadas dos demais direitos? b) Em importando elas em ações positivas do Estado, então podem ser considerados direitos sociais? c) Em se tratando de direitos impostos por normas que garantem a determinados grupos o exercício de direitos fundamentais, não seriam eles transindividuais e, portanto, não poderiam ser denominados de direitos de terceira dimensão; e, ainda, se tiverem como meta a pacificação da sociedade não poderiam ainda ser considerados direitos de quarta geração/dimensão? d) Por fim, esses direitos não deveriam ser permanentes, sob pena de configurar um retrocesso social?

É evidente que não se pretende por esse trabalho responder esses questionamentos. Eles foram elencados para indicar a dificuldade das problemáticas sob o ponto de vista doutrinário e que coloca ainda em cheque a utilização dessadivisão que a clássica doutrina acaba por apresentar e que tem prevalecido nos principais livros jurídicos.

Pensamos que as ações afirmativas, sejam elas para discriminar positivamente, quando presente o fundamento histórico-normativo de déficit de cidadania, não abrangem apenas o direito fundamental à igualdade, que podemos denominar de "direito-fundamento" da ação afirmativa. Elas também vão importar em direitos sociais, com fundamento na desigualdade e na hipossuficiente, que qualificado pelos aspectos históricos a que nos ferimos, exigirão não apenas ações positivas a serem realizadas pelo Estado,mas também, muitas vezes, por instituições privadas, não só para garantir a igualdade substancial sob o prisma dos direitos individuais, mas também dos transindividuais.

Portanto, essas ações afirmativas estarão fundamentalmente ligadas às funções do Estado e de sua relação com toda a sociedade. Nessa linha de raciocínio, a teoria já referida de George Jellinek também se interliga com as funções dos direitos fundamentais, conforme trabalho desenvolvido por J. J. Gomes Canotilho, que os classifica da seguinte maneira e que, no nosso pensar, incide melhor para justificar o conteúdo jurídico das ações afirmativas:função de defesa ou de liberdade; função de prestação social; função de proteção perante terceiros; e função de não discriminação ${ }^{11}$. Vejamos.

A função de defesa ou de respeito às liberdades, em regra vinculada aos direitos fundamentais de primeira dimensão, impõe ao Estado um dever de abstenção, ou seja, de nãointerferência ou de não-intromissão, havendo esta dupla dimensão na leitura do jurista português: "(1) constituem, num plano jurídico-objectivo, normas de competência negativa para os poderes públicos, proibindo fundamentalmente as ingerências destes na esfera jurídica individual; (2) implica, num plano jurídico-subjectivo, o poder de exercer positivamente direitos fundamentais e de exigir omissões dos poderes públicos, de forma a evitar agressões lesivas por parte dos mesmos (liberdade negativa)"12. Ou seja, em se reconhecendo o direito fundamental à ação afirmativa, se assim considerado, deverá a liberdade ser garantida e respeitada no âmbito tanto vertical como horizontal, neste caso, por particulares.

A função de prestação social garante ao indivíduo ou à coletividade, normalmente, o direito de obter uma ação positiva do Estado, impondo-se a este um dever de agir previamente

${ }_{12}^{11}$ Op. cit., p. 407 a 410.

${ }^{12}$ Op. cit, p. 407.

Revista de Direito Brasileira | São Paulo, SP | v. 19 | n. 8 | p. 276 - 297 |Jan./Abr. 2018 
imposto pela Constituição e/ou por regras infraconstitucionais. Na ação estatal afirmativa, o Estado e os destinatários da obrigação - entes públicos ou privados - deverão cumprir as ações positivas a dar efetividade a esses novos direitos.

A função de proteção existirá a fim de que, na conflituosidade da vida cotidiana, os direitos fundamentais não sejam violados, não só pela omissão ou por ato comissivo do Estado, mas também contra atos violadores que sejam praticados pelos próprios membros da sociedade, diante da eficácia horizontal dos direitos fundamentais. Essa proteção há de ser garantida por todos, não só no âmbito administrativo, mas por intermédio do Poder Judiciário.

Há que se salientar que a teoria do status de Jellinek, embora não tenha sido construída para caracterizar os direitos fundamentais, uma vez que desenvolvida a fim de apontar a posição do indivíduo em face do Estado e as situações que eventualmente possam decorrer dessa relação na definição dos seus respectivos direitos e deveres, serviu como importante instrumento político-científico a possibilitar a identificação das espécies e funções dos direitos fundamentais $^{13}$.

Aliás, parece-nos evidente que essas teorias se encontram em planos simétricos, em que podem ser observadas, embora sob perspectivas diferentes, as relações jurídicas e as finalidades dos vários enunciados de direitos fundamentais. Anote-se que a identificação de uma função ou a identificação da natureza de uma determinada relação jurídica entre indivíduo(s) e o Estado será sempre dinâmica, na medida em que, na análise sobre um determinado direito fundamental, a conclusão quanto à sua posição jurídica dentro de um contexto específico há de ser obtida sempre sob a perspectiva da relação subjetiva e da função que se está a debater, considerados os elementos jurídicos e fáticos que envolvam a relação.

Assim, pensamos ser possível, portanto, ainda que transitoriamente, que um país reconheça um direito fundamental instrumental, como é o caso - por exemplo - de direitos fundamentais processuais ou até mesmo de um direito a ação afirmativa, que tenha no conteúdo desse direito não só uma função, mas diversas funções a garantir o atingimento de uma igualdade material.

Para que isso se dê sob uma ótica constitucional e que, portanto, não esteja maculada por um vício de inconstitucionalidade, será exigível que a nação que fizer a sua opção por implantar uma política de ação afirmativa o faça por intermédio de políticas públicas normativas e administrativas que realizem, com absoluta precisão e proporcionalidade, a restrição aos direitos fundamentais das pessoas que não serão beneficiadas por essas ações afirmativas no limite da sua real necessidade.

Não há que se olvidarqueos direitos fundamentais são compostos por princípios e regras, conforme escólio de Robert Alexy. E, como já alertado por Friedrich Müller, é comum que a interpretação sobre a aplicação desses direitos não seja baseada exclusivamente na subsunção, mas na interpretação constitucional - mesmo porque esses princípios se encontram na Carta constitucional de cada país. Também ao aplicador da norma incumbirá a tarefa de, seja este o destinatário ou o simples intérprete, na tarefa de concretização do direito, observar com acuidade a realidade social, na medida em que a norma jurídica não se limita ao seu texto. A normatividade há de ser concretizada mediante um processo estruturado e passível de verificação e de justificação intersubjetiva ${ }^{14}$.

Ao mesmo tempo, anote-se que a norma deve exercer a sua função primária que é a regência da vida em sociedade, com segurança e respeito ao ordenamento jurídico como um todo. Aliás, como já escreveu Hans Kelsen, o direito é um conjunto de normas coativas, a provocar determinados comportamentos e a norma será sempre um "dever ser”, um juízo hipotético que

\footnotetext{
${ }^{13}$ MENDES, Gilmar Ferreira; COELHO, Inocêncio Mártires; BRANCO, Paulo Gustavo Gonet.Hermenêutica constitucional e direitos fundamentais. Brasília: Brasília Jurídica,2002, p. 140.

${ }^{14}$ MÜLLER, Friedrich.Métodos de Trabalho do Direito Constitucional. São Paulo: Max Limonad, 2000, p. 61 - 70. Revista de Direito Brasileira | São Paulo, SP | v. 19 | n. 8 | p. 276 - 297 |Jan./Abr. 2018
} 
expressa uma disposição e/ou uma consequência jurídica e a sua eficácia estará sujeita ao cumprimento fático.

Conforme defendido por Dworkin, os princípios, de seu lado, não desencadeiam automaticamente as consequências jurídicas previstas no texto normativo pela só ocorrência da situação de fato que o texto descreve. Os princípios têm uma dimensão que as regras não possuem: a dimensão de peso. Os princípios podem interferir uns nos outros e, nesse caso, "devese resolver o conflito levando-se em consideração o peso de cada um”. Isso, admitidamente, não se faz por meio de critério de mensuração exatos, mas segundo a indagação sobre quão importante é um princípio - ou qual o seu peso - numa dada situação. Não se resolvem os conflitos entre princípios tomando um como exceção ao outro. O que ocorre é um confronto de pesos entre as normas que se cotejam. Os princípios como delineados por Dworkin, captam os valores morais da comunidade e os tornam elementos próprios do discurso jurídico ${ }^{15}$.

Se hoje temos em todas as Constituições as garantias jurídicas fundamentais à igualdade de tratamento $^{16}$ (igualdade formal), o grande desafio ocorre, portanto, quando por razões históricas, as desigualdades sociais se confrontam com a igualdade jurídica. É evidente que a cultura jurídica legicêntrica que tratava a lei editada pelo Legislativo como fonte principal do Direito se modificou de forma essencial após a Segunda Grande Guerra. Com a conformação de uma teoria dos direitos fundamentais pela constitucionalização dos direitos e mudança de paradigmas relativamente às técnicas hermenêuticas, trouxe a necessidade de se tratar não só das técnicas de ponderação, com o uso frequente do princípio da proporcionalidade não só no âmbito judicial, mas também legislativa, mas tornou-se imperioso o tratamento adequado das hipóteses de restrições ou de limitações aos direitos fundamentais ${ }^{17}$.

Pensamos não existir dúvida de que esse novo pensar, "ao reconhecer a força normativa de princípios revestidos de elevada carga axiológica, como dignidade da pessoa humana, igualdade, Estado Democrático de Direito e solidariedade social", como bem salientado por Daniel Sarmento ${ }^{18}$ ao ser referir aos estudos de Ronald Dworkin, abre as portas do Direito para o debate moral ${ }^{19}$.

A função de não discriminação, corolário do princípio da igualdade, visa assegurar que o Estado trate os seus cidadãos como sendo fundamentalmente iguais, ela exige que se busque, por todas as vias estatais (legislativa, administrativa ou mesmo judicial), que se garanta a igualdade jurídica sempre que necessário.Como ultrapassar essa barreira constitucional sem quebrar a igualdade entre as pessoas consiste no grande debate em nosso país, que foi também objeto dos estudos acadêmicos que restaram analisados. Vejamos no próximo capítulo um breve tratamento sobre a discriminação positiva válida.

\section{IGUALDADEE A QUESTÃO DA DISCRIMINAÇÃO POSITIVA}

A nossa Constituição da República, em seu art. 5º inciso I, estabelece a necessária obediência ao princípio da igualdade, prevendo que "todos são iguais perante a lei". A lei, portanto, não pode ser fonte de privilégios ou de perseguições, mas deve ser um instrumento,

\footnotetext{
${ }^{15}$ MENDES, Gilmar Ferreira; BRANCO, Paulo Gustavo Gonet. Op. cit., 2013, p. 73.

${ }^{16}$ Observe-se que mesmo em países com tradição ditatorial como o da Coreia do Norte, há previsão formal em sua Constituição da igualdade formal.

${ }^{17}$ Vide trabalho publicado especificamente sobre este tema: KIM, Richard Pae. "Separação de poderes e as teorias interna e externa dos direitos fundamentais: direitos sociais e a inaplicabilidade da teoria externa". In, Revista de Direito Brasileira, v. 10, n. 5, 2015, p. 273 a 301. Disponível também em http://www.rdb.org.br/ojs/index.php/rdb/article/view/347.

18 SARMENTO, Daniel. Por um constitucionalismo inclusivo: História Constitucional Brasileira, Teoria da Constituição e Direitos Fundamentais. Rio de Janeiro: Lumen Juris, 2010, p. 241.

${ }^{19}$ DWORKIN, Ronald. Freedom's Law: the Moral reading of the American Constitution. Cambridge: Harvard University Press, 1996.
} 
conforme escólio de Celso Antônio Bandeira de Mello, a regular a vida social que deve tratar equitativamente todos os cidadãos ${ }^{20}$.

Esse valor, portanto, há de ser respeitado por todos, sendo fato que o estabelecimento de hipótesesnormativas discriminadoras, como dispostas pela nossa Carta Maior,serão vedadas nos casos de tratamento diferenciado por motivo de raça, sexo, idade, ideologia política, capacidade econômica e religião, a ensejar numa primeira abordagem proibição efetiva à discriminação com base nesses fatores. Aliás, qualquer discriminação há de ser combatida, podendo em determinadas situações o ato discriminatório configurar crime, como se verifica dos tipos estabelecidos pela Lei $n^{\circ} 7.716 / 1989$, alterada pela Lei $n^{\circ} 9.459 / 1997$, que define os crimes resultados de preconceito de raça ou de cor.

Flávia Piovesan ${ }^{21}$, ao tratar do conteúdo da igualdade, pondera que se destacam três vertentes no que tange à concepção da igualdade: a) igualdade formal, reduzida à fórmula 'todos são iguais perante a lei' (que no seu tempo foi crucial para a abolição de privilégios); b) igualdade material, correspondente ao ideal de justiça social e distributiva (igualdade orientada pelo critério socioeconômico); e c) igualdade material, correspondente ao ideal de justiça como reconhecimento de identidades (igualdade orientada pelos critérios gênero, orientação sexual, idade, raça, etnia e demais critérios).

No entanto, por outro lado, não se impede que num regime jurídico haja a possibilidade de reconhecimento das desigualdades, o que pode autorizar, em situações excepcionais, um tratamento desigual desde que existam reais fatores para uma discriminação relevante, por diferenças biológicas, sociais e econômicas, verbi gratia, mesmo porque não existe, como já salientamos, um princípio absoluto. Aliás, a jurista Cármen Lúcia Antunes Rocha há tempos vem sustentando que o processo histórico comprovou que a promoção do princípio da igualdade, como vinha sendo tratado pelo Direito Constitucional "não foi suficiente para garantir a sua efetividade" ${ }^{22}$, não bastando a simples proibição da discriminação.

O princípio da igualdade proíbe tratamento desuniforme; entretanto, a função precípua da lei em alguns casos pode e deve ser o de discriminar situações, "de maneira que as pessoas compreendidas em umas ou em outras possam ser colhidas pelos diferentes sistemas" 23 . A lei pode, por exemplo, estabelecer condições especiais de acessibilidade às pessoas portadoras de deficiências, "tendo em vista o reconhecimento do elemento diferencial entre estas pessoas e as que possuem condições normais de locomoção" 24 .

Da leitura feita sobre o tema podemos concluir que as ações afirmativas só serão legítimas se a discriminação positiva tiver como base dois elementos que consideramos serem essenciais para a sua validade: a) a hodierna inexistência de oportunidades iguais a determinados grupos: b) e a confirmação de que historicamente as pessoas desse grupo foram vítimas de exclusão social, tendo sido impedidas de exercer seus direitos de forma satisfatória e por isso, restaram alijadas do processo de seleção natural pela própria sociedade ${ }^{25}$.

A discriminação, nesses casos, só pode ser positiva com o objetivo único de dar um tratamento diferenciado àqueles que se encontrem em posição de inferioridade, mas na mesma e exata proporção da diferença apurada.

\footnotetext{
${ }^{20}$ MELLO, Celso Antônio Bandeira. O Conteúdo Jurídico do Princípio da Igualdade. São Paulo: Malheiros, 2011, p. 10.

${ }^{21}$ PIOVESAN, Flávia. Ações afirmativas da perspectiva dos direitos humanos. Cadernos de Pesquisa, v. 35, n. 124, jan./abr. 2005, p. 43 a 55.

${ }_{22}^{22}$ ROCHA, Cármen Lúcia Antunes. Ação afirmativa - o Conteúdo Democrático do Princípio da Igualdade Jurídica. Revista Trimestral de Direito Público, São Paulo, v. 15, 1996, p. 86.

${ }^{23}$ MELLO, Celso Antônio Bandeira. Op. cit., p. 12.

${ }^{24}$ ANSELMO, José Roberto. As ações afirmativas. In: ARAUJO, Luiz Alberto David (Coord.). Efetivando direitos constitucionais. Bauru: EDITE, 2003, p. 134- 135.

${ }^{25}$ Vide: ANSELMO, José Roberto. Op. cit., p. 135 e 136.
}

Revista de Direito Brasileira | São Paulo, SP | v. 19 | n. 8 | p. 276 - 297 |Jan./Abr. 2018 
As definições e posicionamentos de juristas e doutrinadores sobre o conceito e sobre a natureza das ações afirmativas não são consensuais, mas passaram a ser defendidas principalmente pelas minorias tratadas historicamente com discriminação como veremos a seguir.

\section{AÇÕES AFIRMATIVAS E OS CONTORNOS DAS POLÍtiCAS PÚbliCAS NO BRASIL}

As ações afirmativas são instrumentos de promoção da igualdade material ou substancial direcionadas para as minorias sociais, adotadas para aliviar e remediar as condições resultantes de um passado de discriminação. As discriminações positivas exigem ações de implantação e aperfeiçoamento constante, e assim podem se estender por um prazo extenso, mesmo quando não definitivo, apesar de alguns doutrinadores considerarem as ações afirmativas como temporárias.

Embora as ações afirmativas tenham origem nos Estados Unidos da América, em especial, fundadas nas decisões da Suprema Corte que a partir de 1965, a prática se propagou para diversos países, comprometendo não apenas organizações públicas, mas também as privadas, numa nova prática de efetivação do princípio da igualdade. No Brasil, hodiernamente, não há dúvida de que em nosso ordenamento jurídico essas ações possuem respaldo em nossa Carta da República. Pudemos observar dos trabalhos analisadosreferências a diversos de seus dispositivos como, por exemplo, os artigos $1^{\circ}, 3^{\circ}$, inciso III, 37, caput e inciso VIII, 231 e também os artigos $8^{\circ}, 53,54$ e 58 do ADCT.

Pelo que foi possível levantar em nossa pesquisa, os autores convergiram na compreensão de que as ações afirmativas são aquelas que visam remediar processos enquanto resultados de um passado histórico de discriminação, desigualdade e de exclusão. Nesse sentido, fundadas as conclusões no escólio de Joaquim Benedito Barbosa Gomes, as ações afirmativas, “consistem em políticas públicas (e também privadas) voltadas à concretização do princípio constitucional da igualdade material e à neutralização dos efeitos da discriminação racial, de gênero, de idade, de origem nacional, de compleição física e situação socioeconômica (adição nossa). Impostas ou sugeridas pelo Estado, por seus entes vinculados e até mesmo por entidades puramente privadas, elas visam a combater não somente as manifestações flagrantes de discriminação, mas também a discriminação de fundo cultural, estrutural, enraizada na sociedade, 26 .

Segundo Piovesan, as ações afirmativas "[...] constituem medidas especiais e temporárias que, buscando remediar um passado discriminatório, objetivam acelerar o processo com o alcance da igualdade substantiva por parte de grupos vulneráveis, como as minorias étnicas e raciais e as mulheres, entre outros grupos. As ações afirmativas, como políticas compensatórias adotadas para aliviar e remediar as condições resultantes de um passado de discriminação e cumprem uma finalidade pública decisiva para o projeto democrático: assegurar a diversidade e a pluralidade social" 27 .

Para Manoel Gonçalves Ferreira Filho ${ }^{28}$, por sua vez, as medidas devem obedecer à regra da temporariedade, uma vez que não visam criar um status jurídico permanente em favor de um grupo, e sim propiciar a este grupo a igualdade em relação a outros. Desse modo, entende o jurista que tão logo conseguido o objetivo desejado de igualdade substancial, estariam findas as ações afirmativas.

Por outro lado, Sidney Madruga da Silva não concorda com a tese de que as ações afirmativas sejamnecessariamente temporárias, ao argumentar que "[...] não se pode sustentar que

\footnotetext{
${ }^{26}$ GOMES, Joaquim B. Barbosa. Ação Afirmativa e Princípio Constitucional da Igualdade. Rio de Janeiro: Renovar, 2001, p. 6 - 7.

${ }^{27}$ Op. cit., p. 49.

${ }^{28}$ FERREIRA FILHO, Manoel Gonçalves. Aspectos Jurídicos das Ações Afirmativas. Porto Alegre: Revista do TST, v. 69, n. 2 , jul./dez. 2003 , p. 76.
}

Revista de Direito Brasileira | São Paulo, SP | v. 19 | n. 8 | p. 276 - 297 |Jan./Abr. 2018 
as ações afirmativas, em todos os casos, possuam caráter temporário (...) existem agrupamentos minoritários nos quais a implementação e o aperfeiçoamento constante de políticas afirmativas demandariam um lapso de tempo, quando não definitivo" 29 .

Alguns autores concebem as ações afirmativas como sendo de "Justiça compensatória", de conteúdo reparatório; e outros, por outro lado, como sendo de "Justiça distributiva" e inclusiva, importando em distribuição de direitos e vantagens entre a coletividade com base em critérios de equidade e proporcionalidade, ambas destinadas a ressarcir prejuízos outrora causados a determinados grupos sociais.

Sobre a natureza compensatória, Joaquim Barbosa ressalta que a "Justiça compensatória" tem natureza restauradora e visa corrigir os efeitos perversos da discriminação sofrida por sociedades que por longo tempo adotaram políticas de subjugação de um ou vários grupos ou categorias de pessoas por outras. O processo de marginalização social tem sido transmitido às gerações futura, e para esse autor, o preconceito e a discriminação "oficial ou social de que foram vítimas as gerações passadas tendem a se transmitir às gerações futuras, constituindo-se em um insuportável e injusto ônus social, econômico e cultural a ser carregado, no presente, por essas novas gerações" "30.

Quanto ao aspecto distributivo, Sidney Pessoa Madruga da Silva considera que, ao se propor o incremento de políticas de discriminação positiva, respeitados os princípios do pluralismo e da dignidade da pessoa humana, "não se deixa de levar em conta as injustiças cometidas no passado, as quais se refletem nos dias atuais na forma de desvantagens socioeconômicas e, tampouco, deixa-se de considerar que é preciso uma distribuição mais equânime de oportunidades entre aqueles marginalizados socialmente"31.

Pensamos que essas duas concepções não são excludentes. Pelo contrário, os aspectos compensatório e distributivo coexistem, uma vez que nada impede que as justificativas para as ações afirmativas se apoiem tanto nas injustiças cometidas outrora, quanto na necessidade de distribuir benefícios, direitos e posições, que em função da discriminação restaram monopolizadas por certos grupos.

Quanto às formas para a implantação das políticas públicas, há um consenso nos trabalhos analisados, inclusive pelo que se extrai dos resumos das teses e dissertaçõescoletadas, no sentido de que o pressuposto normativo autorizador deve ser preexistente para dar validade a elas. Acompanham assim o posicionamento doutrinário prevalente no sentido de que todo o direito deve ter seu conteúdo determinado pela Constituição e pelo legislador infraconstitucional.

Exige-se uma opção legislativa e, posteriormente, se o caso, uma opção administrativa. Esse pressuposto de validade, assim como em toda a formulação e execução de uma política pública, deve exigir um processo juridicamente disciplinado que concretize uma ação governamental $^{32}$. É evidente que a política pode se limitar a ser legislativa, mas em regra deve respeitar os procedimentos mais comuns: legislativo, de planejamento, orçamentário e administrativo.

Nem se diga que o Governo, ou melhor, a Administração Pública deve manter sempre, pelo fundamento dos princípios da igualdade e da impessoalidade administrativa, a sua neutralidade política. Como bem sustentado pelo eminente jurista Tarcísio Vieira de Carvalho Neto, essa neutralidade é um mito que deve ser rechaçado e no "campo das decisões administrativas relevantes é necessário trilhar a 'neutralidade política possível',33. Relembrando

\footnotetext{
${ }^{29}$ SILVA, Sidney Pessoa Madruga da. Discriminação positiva: ações afirmativas na realidade brasileira. Brasília: Brasília Jurídica, 2005, p. 60.

${ }^{30}$ Op. cit., p. 62.

${ }^{31}$ Op. cit., p. 97.

${ }^{32}$ BUCCI, Maria Paula Dallari. Fundamentos para uma teoria jurídica das políticas públicas. São Paulo: Saraiva, 2013.

${ }^{33}$ CARVALHO NETO, Tarcísio Vieira de. O princípio da impessoalidade nas decisões administrativas. Brasília: Gazeta Jurídica, 2015, p. 46.
}

Revista de Direito Brasileira | São Paulo, SP | v. 19 | n. 8 | p. 276 - 297 |Jan./Abr. 2018 
lições de Odete Medauar, Paulo Otero e Gustavo Zagrebelsky conclui o referido autor que não há Administração sem política e vice-versa, e "mesmo que a politização da Administração seja uma realidade eloquente, [há] campo fértil para a existência de decisões administrativas assentadas em pressupostos políticos e tendo um conteúdo político como objeto, há limites intransponíveis"34, dentre eles: o interesse público; o respeito à separação dos Poderes; a proibição de gerar lesão a pessoas individualmente consideradas; e o respeito à Constituição, em especial, os objetivos fundamentais da República brasileira inscritos no art. $3^{\circ}$, inciso II da CF (construção de uma sociedade livre, justa e solidária).

Não se olvide que tanto as ações afirmativas quanto as políticas públicas socais buscam uma situação de igualdade. No entanto, neste último caso, o Estado busca dar tratamento desigual para situações de desigualdade social e econômica, quando não opta por um serviço universalizado, visando compensar as hipossuficiências.

As ações afirmativas, por outro lado, pretendem compensar uma desigualdade histórica. É certo que há evidente dificuldade na aceitação de algumas ações afirmativas pela sociedade, pois não há dúvida de que nesse processo político de escolha, o Estado acaba primeiramente por reconhecer que praticou uma ilegalidade ou atos ilegítimos (o que é sempre muito complicado) e posteriormente exige de uma nação a compreensão de que é preciso compensar a ilicitude ou licitude injusta que praticou perante um determinado grupo em certo período da história de um povo.

Uma decisão difícil, a toda evidência, mas que quando se verifica estarem presentes os seus pressupostos, exige-se sempre um grande esforço institucional, sendo um dos seus grandes desafios à transversalidade. Essa política afirmativa deve enfrentar desigualdades que derivam de um amplo processo de exclusão social, e "não pode se restringir a ações de responsabilidade de uma única instituição, mas, ao contrário, deve integrar nesse esforço um extenso conjunto de políticas públicas" ${ }^{\text {"35 }}$, com a mobilização de organismos, agentes públicos e a formação de um núcleo articulador e coordenador da política.

\section{O CAMINHO DA PESQUISA E OS RESULTADOS}

A pesquisa, de caráter quantitativo e qualitativo, coletou e observou as produções acadêmicas no Catálogo de Teses e Dissertações da Capes (http://bancodeteses.capes.gov.br/banco-teses/\#!/) a partir do termo chave "ações afirmativas",e para o refinamento dos dados, foi utilizada como grande área de conhecimento as Ciências Sociais Aplicadas e como áreas de conhecimento Direito e Direito Público.

$\mathrm{Na}$ sequência, foram selecionadas as produções acadêmicas que abordavam sobre a temática das ações afirmativas, seja como tema principal, seja quando trabalham com ela como seu pano de fundo, ainda que parcialmente.

Esse levantamento se situa no âmbito de uma pesquisa do tipo "estado do conhecimento", que analisou as investigações realizadas no âmbito dos cursos deMestrado e deDoutorado no campo das ações afirmativas em cursos de pós-graduação stricto sensu brasileiros. Não se trata de um estudo sobre o "estado da arte" uma vez que as publicações são restritas aos mestrados e doutorados. Aliás, como bem salientado por Romanowski e Ens,

[...] para realizar um "estado da arte" (...) não basta apenas estudar osresumos de dissertações e tese, são necessários estudos sobre asproduções e congressos na

\footnotetext{
${ }^{34}$ Op. cit., p. 48 e 49.

35 SILVA, Josenilton; JACCOUD, Luciana; SOARES, Sergei; SILVA, Waldemir. A promoção da igualdade racial no primeiro semestre de 2007 e os programas de ação afirmativa nas universidades públicas. In: JACCOUD, Luciana (Org.). A Construção de uma Política de Promoção da Igualdade Racial: uma análise dos últimos 20 anos. Brasília: Ipea, 2009, p. 174.
}

Revista de Direito Brasileira | São Paulo, SP | v. 19 | n. 8 | p. 276 - 297 |Jan./Abr. 2018 
área, estudos sobre as publicações emperiódicos na área. O estudo que aborda apenas um setor daspublicações sobre o tema estudado vem sendo denominado de "estadodo conhecimento",

Todos os resumos dos sessenta e quatro (64) trabalhos disponibilizados no sítio eletrônico do Catálogo de Teses Dissertações da Capes foram recortados, lidos, categorizados e analisados e parte dessas produções foi objeto de leitura e de reflexões que, no capítulo seguinte, serão singelamente expostos.

Primeiramente foram numerados e organizados em ordem cronológica, Autoria, Título, Universidade/ Estado, com a indicação se se trata de um trabalho de Doutorado ou de Mestrado (Quadro1).

Quadro 1. Dissertações e teses sobre Ações afirmativas/Direito. Período 2013-2016.

\begin{tabular}{|c|c|c|c|c|}
\hline $\mathrm{N}^{\mathrm{O}}$ & Autor & Título & Universidade & $\begin{array}{c}\text { Tese e/ou } \\
\text { Disserta- } \\
\text { ção }\end{array}$ \\
\hline \multicolumn{5}{|c|}{2016} \\
\hline 1 & $\begin{array}{l}\text { Siqueira, } \\
\text { J.C.A }\end{array}$ & Direito como efetividade e luta pela terra no Brasil & $\mathrm{UNB} / \mathrm{DF}$ & Doutorado \\
\hline 2 & Sousa, A.R. & $\begin{array}{l}\text { Concurso público e ações afirmativas: a reserva de cotas sociais como } \\
\text { instrumento de concretização dos direitos fundamentais }\end{array}$ & FADISP/SP & Doutorado \\
\hline 3 & Jesus, A P.R. & $\begin{array}{l}\text { A proteção das pessoas com deficiência por meio das ações afirmativas } \\
\text { no direito tributário }\end{array}$ & $\mathrm{PUC} / \mathrm{SP}$ & Mestrado \\
\hline 4 & $\begin{array}{l}\text { Ferreira, G. } \\
\text { Loures }\end{array}$ & Sub-representação legal: a lei de cotas nos concursos públicos & $\mathrm{UNB} / \mathrm{DF}$ & Mestrado \\
\hline 5 & $\begin{array}{l}\text { Torres, Rafael } \\
\text { Lima }\end{array}$ & $\begin{array}{l}\text { Compliance e a Lei } \mathrm{N}^{\circ} 12.846 / 2013 \text { à luz da análise econômica do } \\
\text { direito }\end{array}$ & $\begin{array}{l}\text { UNICUITIB } \\
\text { A/PR }\end{array}$ & Mestrado \\
\hline 6 & $\begin{array}{l}\text { Armede, } \\
\text { Juliana F. }\end{array}$ & $\begin{array}{l}\text { Tráfico de pessoas e trabalho escravo: ações afirmativas no processo } \\
\text { penal' }\end{array}$ & PUC/SP & Doutorado \\
\hline 7 & $\begin{array}{l}\text { Peixoto, } \\
\text { Pedro Abreu. }\end{array}$ & $\begin{array}{l}\text { A missão da universidade: acesso ao ensino superior e ações } \\
\text { afirmativas }\end{array}$ & PUC/MG & Mestrado \\
\hline 8 & $\begin{array}{l}\text { Castro, } \\
\text { Moises } \\
\text { Coelho }\end{array}$ & $\begin{array}{l}\text { A inclusão das pessoas com deficiência no mercado de trabalho } \\
\text { brasileiro: um estudo das normas e ações afirmativas à luz do direito } \\
\text { internacional }\end{array}$ & UNESP/SP & Mestrado \\
\hline 9 & $\begin{array}{l}\text { Resende, } \\
\text { Emerson A. }\end{array}$ & $\begin{array}{l}\text { O direito fundamental ao trabalho da pessoa com deficiência no Brasil: } \\
\text { caminhos para a eficácia social }\end{array}$ & FUFS/SE & Mestrado \\
\hline 10 & $\begin{array}{l}\text { Matje, } \\
\text { Fernanda B. }\end{array}$ & $\begin{array}{l}\text { Mulher e representação política: uma análise da política de cotas de } \\
\text { gênero no Brasil }\end{array}$ & URI/RG & Mestrado \\
\hline 11 & $\begin{array}{l}\text { Leonardi, } \\
\text { Armenia C.D. }\end{array}$ & $\begin{array}{l}\text { A pessoa idosa socialmente excluída: a preservação do envelhecimento } \\
\text { com dignidade }\end{array}$ & $\mathrm{UCP} / \mathrm{RJ}$ & Mestrado \\
\hline 12 & $\begin{array}{l}\text { Lopes, Karin } \\
\text { Becker }\end{array}$ & $\begin{array}{l}\text { A igualdade substancial entre os sexos: estudo sobre a participação das } \\
\text { mulheres brasileiras na política }\end{array}$ & UNIFOR/CE & Mestrado \\
\hline \multicolumn{5}{|c|}{2015} \\
\hline $\begin{array}{l}1 / 20 \\
15\end{array}$ & $\begin{array}{l}\text { Rotondano, } \\
\text { Ricardo O. }\end{array}$ & $\begin{array}{l}\text { Movimentos sociais e educação jurídica popular: estratégias de atuação } \\
\text { coletiva para a consecução de direitos }\end{array}$ & $\mathrm{UNB} / \mathrm{DF}$ & Mestrado \\
\hline 2 & $\begin{array}{l}\text { Silva, Daniel } \\
\text { A.F. }\end{array}$ & Ações afirmativas voltadas ao cárcere & UESá/RJ & Mestrado \\
\hline 3 & $\begin{array}{l}\text { Conceicao, } \\
\text { Ana C.N. }\end{array}$ & Exame sobre os limites do paternalismo nas ações afirmativas no Brasil & UFB/BA & Mestrado \\
\hline 4 & $\begin{array}{l}\text { Prosdocimi, } \\
\text { Adolfo C.R. }\end{array}$ & Os deveres fundamentais e a solidariedade tributária fraterna' & UENPR/PR & Mestrado \\
\hline 5 & $\begin{array}{l}\text { Leite, Jose } \\
\text { Luiz }\end{array}$ & $\begin{array}{l}\text { Pessoa com deficiência e o mercado de trabalho: evolução, dificuldades } \\
\text { e superação }\end{array}$ & CUBauru/SP & Mestrado \\
\hline 6 & $\begin{array}{l}\text { Hippler, } \\
\text { Aldair }\end{array}$ & $\begin{array}{l}\text { Políticas públicas, ações afirmativas e a efetivação dos direitos } \\
\text { humanos }\end{array}$ & URNRG/RG & Mestrado \\
\hline 7 & $\begin{array}{l}\text { Vasconcelos, } \\
\text { Silvia A. }\end{array}$ & $\begin{array}{l}\text { Acesso ao ensino superior e ações afirmativas: bolsas de estudo } \\
\text { integrais }\end{array}$ & PUC/SP & Doutorado \\
\hline 8 & $\begin{array}{l}\text { Lemos, } \\
\text { Isabele B. }\end{array}$ & $\begin{array}{l}\text { Cotas raciais na UFPA: as percepções de estudantes cotistas sobre suas } \\
\text { trajetórias acadêmicas }\end{array}$ & UFPA/PA & Mestrado \\
\hline 9 & $\begin{array}{l}\text { Miguel, Jose } \\
\text { Antonio }\end{array}$ & A negociação coletiva de trabalho como meio de inclusão social & UENPR/PR & Mestrado \\
\hline 10 & $\begin{array}{l}\text { Lima, } \\
\text { Fernando }\end{array}$ & $\begin{array}{l}\text { Igualdade e inclusão: a reserva de vagas para pessoas com deficiência } \\
\text { no serviço público }\end{array}$ & USP/SP & Doutorado \\
\hline
\end{tabular}

${ }^{36}$ ROMANOWSKI, Joana Paulin; ENS, Romilda Teodora. As Pesquisas Denominadas do Tipo 'Estado da Arte' em Educação.Revista Diálogo Educacional, v. 6, n. 19, 2006, p. 39 e 40.

Revista de Direito Brasileira | São Paulo, SP | v. 19 | n. 8 | p. 276 - 297 |Jan./Abr. 2018 


\begin{tabular}{|c|c|c|c|c|}
\hline & G.S. & & & \\
\hline 11 & $\begin{array}{l}\text { Matos, } \\
\text { Simone A. de }\end{array}$ & $\begin{array}{l}\text { A (re) construção histórica da identidade cidadã das mulheres: um } \\
\text { diálogo que perpassa o feminismo e as políticas públicas no Brasil pós- } \\
\text { transição democrática }\end{array}$ & URI/RG & Mestrado \\
\hline 12 & $\begin{array}{l}\text { Soares, } \\
\text { Ircineide S. }\end{array}$ & $\begin{array}{l}\text { Políticas públicas no Brasil e os programas de educação e trabalho para } \\
\text { a emancipação da mulher }\end{array}$ & CUCU/PR & Mestrado \\
\hline 13 & $\begin{array}{l}\text { Puerari, } \\
\text { Daniel N. }\end{array}$ & $\begin{array}{l}\text { A intervenção estatal na autonomia privada: uma abordagem das } \\
\text { intervenções estatais na vida dos moradores de rua da cidade do Rio de } \\
\text { Janeiro }\end{array}$ & $\mathrm{UCP} / \mathrm{RJ}$ & Mestrado \\
\hline 14 & $\begin{array}{l}\text { Barros, } \\
\text { Joseane B.A. }\end{array}$ & $\begin{array}{l}\text { Educação jurídica e direitos humanos: o caso do curso de direito com } \\
\text { os assentados da reforma agrária }\end{array}$ & $\mathrm{UFPB} / \mathrm{PB}$ & Mestrado \\
\hline 15 & $\begin{array}{l}\text { Alves, } \\
\text { Adriana } \mathrm{T} \text {. }\end{array}$ & $\begin{array}{l}\text { Novo modelo de atuação da defensoria pública: para além da igualdade } \\
\text { estritamente formal }\end{array}$ & UERJ/RJ & Doutorado \\
\hline 16 & $\begin{array}{l}\text { Moretti, } \\
\text { Vanessa C. }\end{array}$ & $\begin{array}{l}\text { Do cumprimento das decisões dos órgãos internacionais de defesa da } \\
\text { mulher no combate à desigualdade de gênero }\end{array}$ & CUFIEO/SP & Mestrado \\
\hline 17 & $\begin{array}{l}\text { Gomes, } \\
\text { Djalma M. }\end{array}$ & A tributação e a inclusão da pessoa com deficiência & $\mathrm{PUC} / \mathrm{SP}$ & Mestrado \\
\hline \multicolumn{5}{|c|}{2014} \\
\hline $\begin{array}{l}1 / 20 \\
14\end{array}$ & $\begin{array}{l}\text { Santos, Aline } \\
\text { S. Salles }\end{array}$ & Os concursos públicos no campo jurídico- acadêmico & $\mathrm{UNB} / \mathrm{DF}$ & Doutorado \\
\hline 2 & $\begin{array}{l}\text { Valle, Luisa } \\
\text { de Pinho }\end{array}$ & $\begin{array}{l}\text { Estudo sobre educação como prática da democracia e a experiência } \\
\text { das cidades educativas }\end{array}$ & UNB/DF & Mestrado \\
\hline 3 & $\begin{array}{l}\text { Belmonte, } \\
\text { Renata L.C. }\end{array}$ & $\begin{array}{l}\text { Quotas para mulheres em conselhos de administração, à luz da teoria } \\
\text { feminista do direito }\end{array}$ & USP/SP & Doutorado \\
\hline 4 & $\begin{array}{l}\text { Silva, Eraldo } \\
\text { Melo }\end{array}$ & $\begin{array}{l}\text { O persistente problema racial: quem é negro no Brasil? A } \\
\text { inconstitucionalidade das ações afirmativas de viés racial em face da } \\
\text { ausência em face da ausência de critérios objetivos de discrímen }\end{array}$ & IDP/DF & Mestrado \\
\hline 5 & $\begin{array}{l}\text { Silveira, } \\
\text { Adinan R. }\end{array}$ & $\begin{array}{l}\text { O multiculturalismo e os mecanismos de proteção juridíco-politico } \\
\text { para a minoria Afro-Brasileira }\end{array}$ & UESá/RJ & Mestrado \\
\hline 6 & $\begin{array}{l}\text { Maia, } \\
\text { Mauricio }\end{array}$ & Pessoas com deficiência e concurso público & $\mathrm{PUC} / \mathrm{SP}$ & Mestrado \\
\hline 7 & $\begin{array}{l}\text { Trippia, } \\
\text { Luciane } \\
\text { Maria }\end{array}$ & $\begin{array}{l}\text { A discriminação da mulher negra no mercado de trabalho e as cotas } \\
\text { raciais }\end{array}$ & $\begin{array}{l}\text { CUCURITIBA/ } \\
\text { PR }\end{array}$ & Mestrado \\
\hline 8 & $\begin{array}{l}\text { Venturini, } \\
\text { Anna C. }\end{array}$ & $\begin{array}{l}\text { Ações afirmativas e o ingresso nas universidades públicas brasileiras } \\
\text { - análise sob o ponto de vista da formulação de políticas públicas }\end{array}$ & USP/SP & Mestrado \\
\hline 9 & $\begin{array}{l}\text { Silva, Monica } \\
\text { A.M. }\end{array}$ & $\begin{array}{l}\text { A prevenção criminal em uma nova perspectiva: ações afirmativas } \\
\text { como medida de redução da vulnerabilidade de egresso do sistema } \\
\text { carcerário brasileiro }\end{array}$ & UFBA/BA & Mestrado \\
\hline 10 & $\begin{array}{l}\text { Resque, Joao } \\
\text { D. Daibes }\end{array}$ & $\begin{array}{l}\text { O conceito normativo de pessoa com deficiência para fins de reserva } \\
\text { de vagas ao mercado de trabalho }\end{array}$ & UFPA/PA & Mestrado \\
\hline 11 & $\begin{array}{l}\text { Machado, } \\
\text { Monica S. }\end{array}$ & $\begin{array}{l}\text { A lei de cotas no poder legislativo: uma análise da representação } \\
\text { feminina na política partidária brasileira }\end{array}$ & UPMak/SP & Mestrado \\
\hline 12 & $\begin{array}{l}\text { Conceicao, } \\
\text { Isis A. }\end{array}$ & $\begin{array}{l}\text { Movimentos sociais e judiciário: uma análise comparativa entre } \\
\text { Brasil e Estados Unidos da América do Norte }\end{array}$ & USP/SP & Doutorado \\
\hline 13 & $\begin{array}{l}\text { Nabeshima, } \\
\text { Yuri Kuroda }\end{array}$ & $\begin{array}{l}\text { A discriminação da mulher no mercado de trabalho - estudo } \\
\text { comparado da legislação do Brasil e Japão }\end{array}$ & USP/SP & Mestrado \\
\hline 14 & $\begin{array}{l}\text { Silva, } \\
\text { Elisabeth } \\
\text { M.M. }\end{array}$ & $\begin{array}{l}\text { Os portadores de TDAH e a atuação do estado do Mato Grosso do } \\
\text { Sul }\end{array}$ & UNIVEM/SP & Mestrado \\
\hline 15 & $\begin{array}{l}\text { Rivero, } \\
\text { Carolina C. } \\
\end{array}$ & $\begin{array}{l}\text { Os direitos fundamentais sociais como instrumentos para a } \\
\text { concretização do princípio da igualdade }\end{array}$ & UNIMEP/SP & Mestrado \\
\hline 16 & $\begin{array}{l}\text { Ramos, Izabel } \\
\text { Christina }\end{array}$ & $\begin{array}{l}\text { A negociação coletiva como instrumento de efetividade do direito } \\
\text { fundamental à igualdade }\end{array}$ & UFRN/RN & Mestrado \\
\hline 17 & $\begin{array}{l}\text { Andrade Jr, } \\
\text { Marcelo O.S. }\end{array}$ & $\begin{array}{l}\text { A igualdade formal ante a desigualdade material na relação de } \\
\text { emprego doméstico no Brasil }\end{array}$ & UFPB/PB & Mestrado \\
\hline 18 & $\begin{array}{l}\text { Iensue, } \\
\text { Geziela }\end{array}$ & $\begin{array}{l}\text { A legitimidade jurídico-ética da política de cotas raciais no Brasil: } \\
\text { uma visão a partir da perspectiva capacitária e do desenvolvimento } \\
\text { como liberdade }\end{array}$ & UFPR/PR & Doutorado \\
\hline \multicolumn{5}{|c|}{2013} \\
\hline $\begin{array}{l}1 / 20 \\
13\end{array}$ & $\begin{array}{l}\text { Oliveira, } \\
\text { Renato Neves }\end{array}$ & ações afirmativas no mercado de trabalho' & $\mathrm{PUC} / \mathrm{SP}$ & Mestrado \\
\hline 2 & $\begin{array}{l}\text { Felberg, } \\
\text { Rodrigo }\end{array}$ & $\begin{array}{l}\text { A reintegração social dos cidadãos-egressos, uma nova dimensão de } \\
\text { aplicabilidade às ações afirmativas }\end{array}$ & UPMak/SP & Doutorado \\
\hline 3 & $\begin{array}{l}\text { Dubugras, } \\
\text { Regina M.V. }\end{array}$ & $\begin{array}{l}\text { As medidas de ação afirmativa nas relações de trabalho: por um } \\
\text { sistema de metas }\end{array}$ & USP/SP & Doutorado \\
\hline 4 & $\begin{array}{l}\text { Moraes, Luis } \\
\text { E.N. }\end{array}$ & Ações afirmativas, igualdade racial e o direito como integridade & URI/RG & Mestrado \\
\hline 5 & $\begin{array}{l}\text { Filho, } \\
\text { Fernando } \\
\text { P.S.M. }\end{array}$ & $\begin{array}{l}\text { A (re)inclusão social dos apenados e dos egressos do sistema } \\
\text { prisional pela maximização da responsabilidade social empresarial } \\
\text { estimulada na seara das licitações e dos contratos administrativos }\end{array}$ & $\begin{array}{l}\text { CUCURITIBA/ } \\
\text { PR }\end{array}$ & Mestrado \\
\hline
\end{tabular}

Revista de Direito Brasileira | São Paulo, SP | v. 19 | n. 8 | p. 276 - 297 |Jan./Abr. 2018 


\begin{tabular}{|c|c|c|c|c|}
\hline 6 & $\begin{array}{l}\text { Almeida, } \\
\text { Thaiana B.O. }\end{array}$ & $\begin{array}{l}\text { Ações afirmativas: a constitucionalidade da política de cotas para } \\
\text { negros em universidades brasileiras }\end{array}$ & UFPA/PA & Mestrado \\
\hline 7 & $\begin{array}{l}\text { Barbosa, } \\
\text { Karin A. }\end{array}$ & $\begin{array}{l}\text { O direito fundamental à educação da pessoa com deficiência, ações } \\
\text { afirmativas }\end{array}$ & UNIMEP/SP & Mestrado \\
\hline 8 & $\begin{array}{l}\text { Froede, } \\
\text { Cristina G.M. }\end{array}$ & $\begin{array}{l}\text { Ações afirmativas e acessibilidade como instrumentos de efetivação } \\
\text { do princípio da igualdade para as pessoas com deficiência }\end{array}$ & FUMED/MG & Mestrado \\
\hline 9 & $\begin{array}{l}\text { Teixeira, } \\
\text { Rafael S. }\end{array}$ & $\begin{array}{l}\text { A igualdade e as ações afirmativas: a luta pelo reconhecimento dos } \\
\text { grupos de vulnerabilidade }\end{array}$ & $\begin{array}{l}\text { UniCesumar/ } \\
\text { PR }\end{array}$ & Mestrado \\
\hline 10 & $\begin{array}{l}\text { Bueno, Sergio } \\
\text { Luiz Jose }\end{array}$ & $\begin{array}{l}\text { A reserva de vagas à pessoa com deficiência nos concursos públicos: } \\
\text { as diversas faces de inclusão justa }\end{array}$ & CUBauru/SP & Mestrado \\
\hline 11 & $\begin{array}{l}\text { Jesus, } \\
\text { Vinicius M. }\end{array}$ & $\begin{array}{l}\text { Do silêncio ao Estatuto da Igualdade Racial: os caminhos da } \\
\text { igualdade no direito brasileiro }\end{array}$ & USP/SP & Mestrado \\
\hline 12 & $\begin{array}{l}\text { Uliana, Kelly } \\
\text { Ferreira. }\end{array}$ & $\begin{array}{l}\text { Ação afirmativa como meio de proteção aos direitos da criança e do } \\
\text { adolescente vulnerável }\end{array}$ & UNIPAR/PR & Mestrado \\
\hline 13 & $\begin{array}{l}\text { Pinto, Simone } \\
\text { X. Pereira }\end{array}$ & $\begin{array}{l}\text { Assédio moral no meio ambiente laboral e sua repercussão nos } \\
\text { direitos da personalidade com enfoque no gênero feminino }\end{array}$ & $\begin{array}{l}\text { UniCesumar/ } \\
\text { PR }\end{array}$ & Mestrado \\
\hline 14 & $\begin{array}{l}\text { Mello, } \\
\text { Marcus R. M. }\end{array}$ & Cotas sócio raciais em universidades & UFAL/AL & Mestrado \\
\hline 15 & $\begin{array}{l}\text { Carvalho, } \\
\text { Patricia C.B. }\end{array}$ & Aplicabilidade prática da lei Maria da Penha & FUFS/SE & Mestrado \\
\hline 16 & $\begin{array}{l}\text { Gavião, } \\
\text { Vanessa C. }\end{array}$ & $\begin{array}{l}\text { As cotas no ensino superior público brasileiro como ação afirmativa: } \\
\text { uma construção a partir da hermenêutica política de Ronald Dworkin }\end{array}$ & FDSM/MG & Mestrado \\
\hline 17 & $\begin{array}{l}\text { Maciel, } \\
\text { Larissa B. }\end{array}$ & $\begin{array}{l}\text { A agroecologia e o ordenamento jurídico brasileiro: o } \\
\text { desenvolvimento de políticas públicas agroecológicas para o alcance } \\
\text { da sustentabilidade e para a efetivação do Artigo } 225 \text { da Constituição } \\
\text { Federal' }\end{array}$ & PUC/PR & Mestrado \\
\hline
\end{tabular}

A seguir, as produções acadêmicas foram categorizadas pela titulação, região do país, principais temáticas e ano da correspondente produção. No período de 2013 a 2016 foram produzidas: doze (12) teses de Doutorado, o que equivale a $18,75 \%$ da produção, e cinquenta e duas (52) dissertações de Mestrado, refletindo 81,25\% do total.

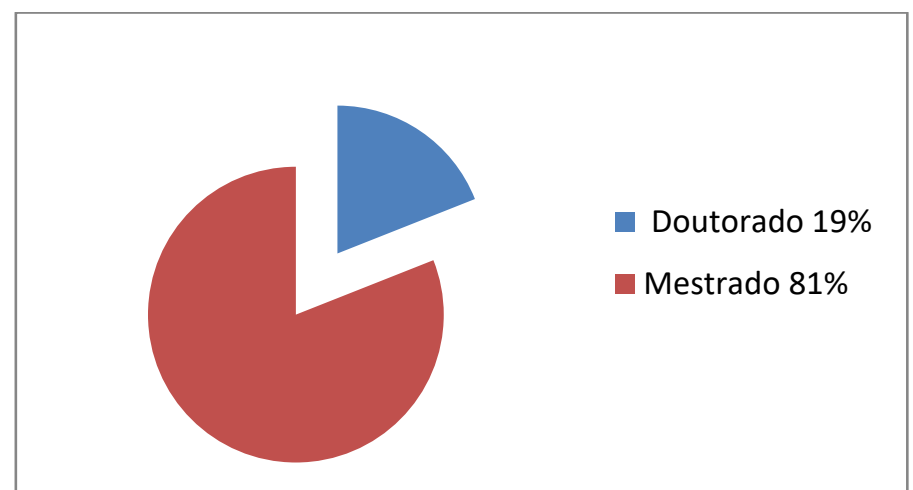

Figura 1. Produções acadêmicas em nível de mestrado e de doutorado

Sob o ponto de vista de produção científica por região do país, lembrando que no Brasil, de acordo com a CAPES, temos noventa e nove (99) cursos de Mestrado Acadêmico e trinta e seis (36) cursos de Doutorado em $2016^{37}$ (na área do Direito), a sua grande maioria resultou das pesquisas realizadas na região Sudeste $(45,3 \%)$, um quarto delas da região Sul (25\%) e o restante, na ordem, no Nordeste (14\%), Centro-Oeste $(9,4 \%)$ e Norte $(6,3 \%)$, acompanhando assim a mesma porcentagem dos cursos de pós-graduação, divididos por regiões, aprovados pela CAPES, conforme se extrai também da Plataforma Sucupira. Portanto, podemos concluir que restou mantida a proporcionalidade da produção desses temas com a quantidade de cursos de pósgraduação stricto sensu existente em cada região do Brasil.

\footnotetext{
${ }^{37}$ Vide Plataforma Sucupira, referência em https://sucupira.capes.gov.br/sucupira/public/consultas/coleta/programa/quantitativos/quantitativoAreaAvaliacao.jsf;j sessionid=IpC19tcuSCVdbQWNHKsjYjWE.sucupira-213. Acesso em 21.12.2017.
} 


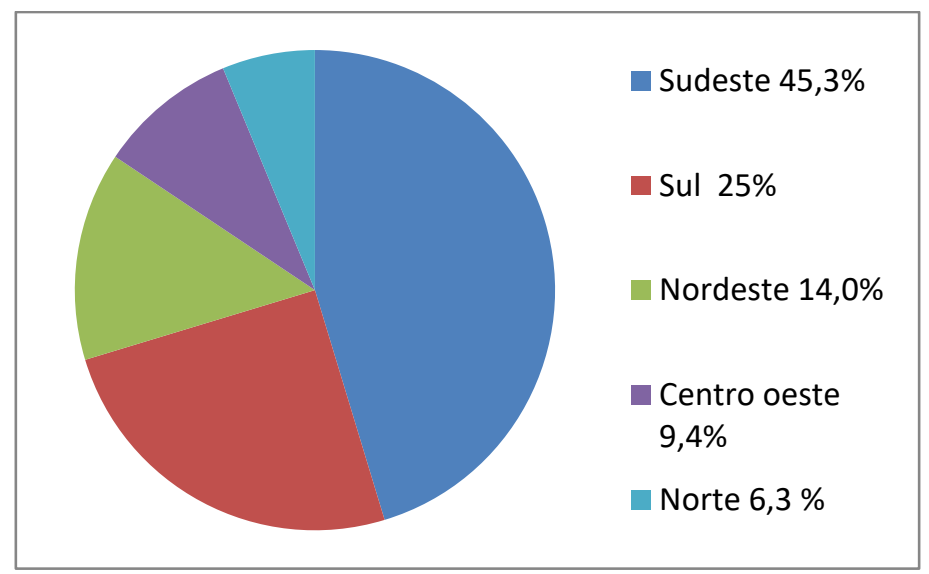

Figura 2. Produções acadêmicas por região do território nacional.

A concentração das pesquisas em ações afirmativas para negros $(23,4 \%)$, mulheres $(20,3 \%)$ e pessoas com deficiência $(17,1 \%)$ pautaram as principais produções, mas não ficaram de fora alguns temas essenciais envolvendo algumas minorias como os egressos do universo carcerário, crianças e adolescentes, idosos, pessoas com transtorno de déficit de atenção, movimentos sociais, moradores de rua e vítimas de tráfico de pessoas e de trabalho escravo, por exemplo, como se verifica dos quadros que seguem abaixo:

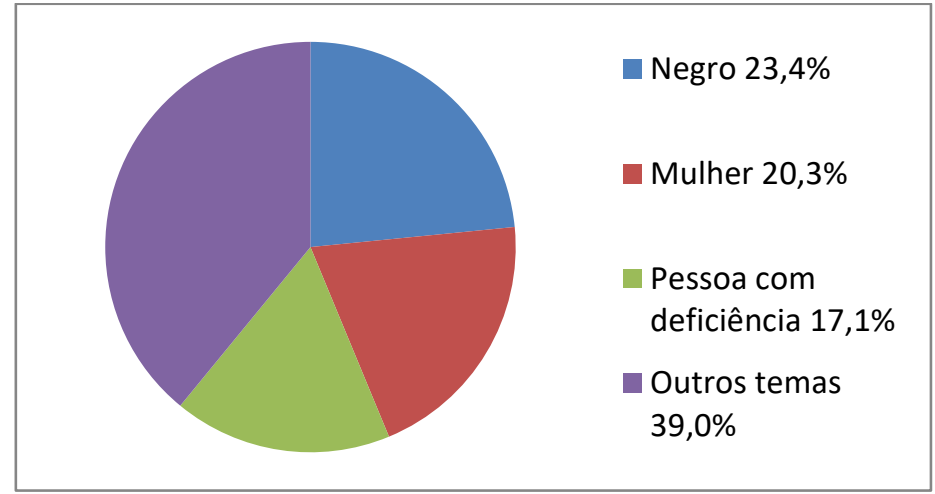

Figura 3. Temas das ações afirmativas das produções acadêmicas

Quadro 2.Temática/Ações Afirmativas X Ano de Publicação/Trabalhos ${ }^{38}$

\begin{tabular}{|l|l|}
\hline $\begin{array}{l}\text { Temáticas/Ações } \\
\text { Afirmativas }\end{array}$ & Ano/n ${ }^{\text {Trabalho }}$ \\
\hline \multirow{3}{*}{ Negro } & \\
& $2013-[3 ; 4 ; 6 ; 11 ; 14 ; 16]$ \\
& $2014-[4 ; 5 ; 8 ; 12 ; 18]$ \\
& $2015-[3 ; 8]$ \\
& $2016-[2 ; 4]$ \\
\hline \multirow{3}{*}{ Mulher } & $2013-[1 ; 13 ; 15]$ \\
& $2014-[3 ; 7 ; 11 ; 13 ; 17]$ \\
& $2015-[11 ; 12 ; 16]$ \\
& $2016-[10 ; 12]$ \\
\hline
\end{tabular}

${ }^{38}$ Trabalhos relacionados no Quadro 1.

Revista de Direito Brasileira | São Paulo, SP | v. 19 | n. 8 | p. 276 - 297 |Jan./Abr. 2018 


\begin{tabular}{|l|l|}
\hline Pessoa com deficiência & $2013-[7 ; 8 ; 10]$ \\
& $2014-[6 ; 10]$ \\
$2015-[5 ; 10 ; 17]$ \\
$2016-[3 ; 8 ; 9]$
\end{tabular}

Quadro 3. Temática X Ano de Publicação/Trabalhos ${ }^{39}$

\begin{tabular}{|l|l|}
\hline Outras temáticas & Ano/ trabalho \\
\hline Criança/adolescente & $2013-[10]$ \\
\hline Reintegração carcerária & $2013-[2,5] ; 2014$ [9]; \\
& $2015[2]$ \\
\hline Grupos vulneráveis & $2013-[9]$ \\
\hline Agroecologia & $2013-[17]$ \\
\hline Transtorno de déficit de atenção & $2014-[14]$ \\
\hline Principio da igualdade & $2014-[15 ; 16]$ \\
\hline Concursos públicos & $2014-[1]$ \\
\hline Cidade Inteligente & $2014-[02]$ \\
\hline Movimentos sociais & $2015-[1]$ \\
\hline Solidariedade tributária & $2015-[4]$ \\
\hline Direitos humanos & $2015-[6]$ \\
\hline $\begin{array}{l}\text { Acesso ensino superior/bolsas de } \\
\text { estudo }\end{array}$ & $2015-[7] ; 2016[7]$ \\
\hline Negociação coletiva trabalho & $2015-[9]$ \\
\hline Morador de rua & $2015-[13]$ \\
\hline Reforma agraria & $2015-[14]$ \\
\hline Defensoria pública & $2015-[15]$ \\
\hline Direito e luta pela terra & $2016-[1]$ \\
\hline Compliance e corrupção & $2016-[5]$ \\
\hline $\begin{array}{l}\text { Tráfico de pessoas e trabalho } \\
\text { escravo }\end{array}$ & $2016-[6]$ \\
\hline Pessoa idosa & $2016-[11]$ \\
\hline & \\
\hline
\end{tabular}

\section{ANÁLISE DOS RESULTADOS E ALGUMAS LACUNAS}

Não há dúvida de que as ações afirmativas, enquanto políticas estatais e de organizações sociais, têm sofrido inúmeras críticas, em especial, aquelasligadas a cotas raciais.A primeira crítica, relativamente à dificuldade de se identificar com clareza as pessoas brancas e negras, em especial, diante da grande miscigenação em nosso país, o que autorizaria o oportunismo de alguns indivíduos, acabou por ser rechaçada pelos trabalhos fundados na própria razoabilidade dos critérios estabelecidos pelas regras já reconhecidas como legítimas pelo Supremo Tribunal Federal.

No julgamento da Arguição de Descumprimento de Preceito Fundamental - ADPF no 186, promovida pelo Partido Democratas - DEM, o Plenário do Supremo Tribunal Federal considerou constitucional a política de cotas étnico-raciais para seleção de estudantes da Universidade de Brasília (UnB). Seguindo o voto do Relator, Ministro Ricardo Lewandowski, restou decidido que as políticas de ação afirmativa adotadas pela UnB estabelecem um ambiente acadêmico plural e diversificado, e têm o objetivo de superar distorções sociais historicamente

${ }^{39}$ Trabalhos relacionados no Quadro 1.

Revista de Direito Brasileira | São Paulo, SP | v. 19 | n. 8 | p. 276 - 297 |Jan./Abr. 2018 
consolidadas. Entendeu-se que a reserva de $20 \%$ de suas vagas para estudantes negros e 'de um pequeno número delas' para índios de todos os Estados brasileiros pelo prazo de 10 anos constituiu numa providência adequada e proporcional ao atingimento dos mencionados objetivos (DJe 20/10/04).

Observe-se que o autor da ação alegou que essa política de cotas adotada na UnB feriria vários preceitos fundamentais da Constituição Federal, como os princípios da dignidade da pessoa humana, de repúdio ao racismo e da igualdade, entre outros, além de dispositivos que estabelecem o direito universal à educação.

Nessa mesma esteira, em recente decisão de nossa Suprema Corte, o seu Plenário, ao julgar a Ação Declaratória de Constitucionalidade - ADC no 41, em que foi relator o eminente Ministro Roberto Barroso, o Supremo Tribunal Federal reconheceu a constitucionalidade da Lei $\mathrm{n}^{\circ}$ 12.990/14 que prevê a reserva de $20 \%$ das vagas oferecidas em concursos públicos para provimento de cargos efetivos e empregos públicos no âmbito da administração pública federal direta e indireta, no âmbito dos três Poderes. Essa decisão, que foi unânime, considerou, dentre outros fundamentos, que a lei é motivada por um dever de reparação histórica decorrente da escravidão e de um racismo estrutural existente na sociedade brasileira (acórdão publicado no DJe 17/08/17).

Merecem registro alguns trechos dos votos proferidos nesse julgamento e que bem elencamimportantes aspectos que devem ser considerados na implantação de políticas de discriminação positiva, a saber: a) a ação afirmativa pode ser delineada por lei (formal) ou por ato normativo; b) os limites da ação afirmativa devem ser absolutamente respeitados, não se podendo aplicar a analogia ou interpretação extensiva; c) o reconhecimento do déficit de cidadania a determinado grupo deve estar comprovado.

Vejamos alguns desses importantes votos e que foram bem registrados no sítio eletrônico do Supremo Tribunal Federal:

O Ministro Dias Toffoli, na oportunidade, bem ressaltou que durante a sua gestão na Advocacia Geral da União reconheceu a constitucionalidade das ações afirmativas e salientou que naquele julgamento o seu voto restringia os efeitos da decisão para os casos de provimento por concurso público, em todos os órgãos dos Poderes da União, não se estendendo para os Estados, Distrito Federal e municípios, uma vez que a lei se destina a concursos públicos na administração direta e indireta da União, e deve ser respeitada a autonomia dos entes federados.

O Ministro Ricardo Lewandowski, por sua vez, recordou-se de que em sua gestão à frente do Conselho Nacional de Justiça (CNJ), foi editada a Resolução 203/2015, que reservava $20 \%$ de vagas para os negros no âmbito do Poder Judiciário. A resolução levou em conta, segundo ele, o primeiro censo do Judiciário realizado pelo Conselho, que apontou que apenas 1,4\% dos juízes brasileiros se declararam negros, e apenas $14 \%$ pardos, dados que divergiam dos números do censo demográfico brasileiro de 2010, do IBGE, segundo o qual o percentual da população brasileira que se declarou negra foi de $7,6 \%$ e parda $43,1 \%$.

O Ministro Marco Aurélio revelou que, nos anos de 2001 e 2002, quando ocupou a presidência do STF, e diante de quadro que persiste até os dias atuais, determinou que fosse inserida em edital para contratação de prestadores de serviço a exigência de reserva de $30 \%$ das vagas para prestação de serviços por negros. Para o ministro, uma sociedade justa e solidária repousa no tratamento igualitário, mas é notória a falta de oportunidade para os negros, frisou o ministro, concordando que as estatísticas sobre a questão são vergonhosas.

A segunda crítica, no sentido de que a universalização das políticas seria a melhor opção política para a solução das diferenças sociais tem, igualmente, sido rebatida, e bem rebatida, pelos dados que essas pesquisasacabaram por se utilizar, extraídos de levantamentos oficiais (ainda no que toca às ações afirmativas de igualdade racial).

Não há espaço para a análise das centenas de dados levantados nos trabalhos de Mestrado e de Doutorado, mas os números do IPEA e do IBGE, bem como os estudos elaborados 
pela Secretaria Especial de Políticas de Promoção da Igualdade Racional (Seppir) ${ }^{40}$, a partir de 2003, acabaram por confirmar a presença dos dois requisitos a que nós nos referimos no Capítulo 2 deste artigo, tudo a autorizar a necessidade da realização imediata das políticas afirmativas raciais, quais sejam: a) a hodierna inexistência de oportunidades iguais a determinados grupos: b) e a confirmação de que historicamente as pessoas desse grupo foram vítimas de exclusão social, tendo sido impedidas de exercer seus direitos de forma satisfatória e por isso, restaram alijadas do processo de seleção natural pela própria sociedade.

Aliás, a confirmar essa necessidade, acentue-se a recentíssima pesquisa realizada pelo IBGE, divulgada no último dia 21 de dezembro de $2017^{41}$, em que ficou evidenciado o mencionado abismo social. Em 2016 o país tinha 11,8 milhões de analfabetos, a representar 7,2\% da população de 15 anos ou mais, sendo que a taxa entre pretos e pardos é de 9,9\%, mais do que o dobro da de pessoas brancas (4,2\%), tudo a açambarcar os demais estudos no sentido de que brancos têm mais acesso à educação em nosso país do que negros. No caso dos idosos, a diferença racial também está presente: a taxa de analfabetismo entre pretos e pardos com mais de 60 anos é de 30,7\%, enquanto que o mesmo indicador para brancos alcança 11,7\% dessa população.

Com o devido respeito, sentimos a falta nos trabalhos apresentados, de um maior aprofundamento quanto aos critérios utilizados em diversos países em que se deu a implantação de políticas públicas de discriminação positiva; a construção de critérios universais para a escolha de uma ação afirmativa e, em especial, das experiências exitosas quanto às políticas implantadas. Não se está a desmerecer os trabalhos defendidos nas universidades. O que se coloca é a necessidade de futuro aprimoramento daquilo que se produziu nesse período.

Verificamos, ainda, a ausência de alguns temas que seriam igualmente importantes para a fixação de algumas políticas públicas de discriminação positiva envolvendo grupos historicamente marginalizados, a saber: os índios, comunidades quilombolas, sem-teto e semterra, homossexuais e os transexuais. É certo que temos algumas produções, mas efetivamente poderiam ter sido ampliadas essas discussões em trabalhos mais específicos.

\section{CONSIDERAÇÕES FINAIS}

O trabalho teve a pretensão de oferecer ao leitor uma visão panorâmica de uma parte da produção acadêmica brasileira sobre ações afirmativas na área do Direito, no período de 2013 a 2016.

Observa-se uma concentração de trabalhos na região Sudeste, dado o maior número de programa de pós-graduação em Direito, e uma atenção maior a temas como negro, mulher e pessoas com deficiência em detrimento de outros igualmente importantes.

No Quadro 2, ressalta-se que a questão das cotas foi um assunto estudado por muitos pesquisadores em 2013 e 2014, com 11 pesquisas, sendo que em 2015 e 2016 esse número acabou sendo menor (4 pesquisas). A temática envolvendo mulher e pessoas com deficiência manteve um número similar de interesse por parte dos alunos de pós-graduação. Como já salientado, não houve a produção de trabalhos voltados a grupos indígenas e aos sem-terra, que mantém em seu grupo, pessoas originárias dos quilombos. O problema da posse e uso da terra foi assunto pouco estudado, mesmo com toda a violência envolvendo esses grupos historicamente

\footnotetext{
${ }^{40}$ Secretaria criada com status de Ministério e tendo como objetivo formular e coordenar políticas e articular ações de governo federal de combate à discriminação e à desigualdade racial. Não há que se olvidar também que foram criados o Conselho Nacional de Promoção da Igualdade Racial (CNPIR), o Fórum Intergovernamental de Promoção da Igualdade Racial (Fipir) e o Sistema Nacional de Promoção da Igualdade Racial (Sinapir), este criado pelo Estatuto da Igualdade Racial e regulamentado pelo Decreto $n^{\circ}$ 8.136/13.

${ }^{41}$ Publicado na Folha UOL. Educação. Disponível em: http://www1.folha.uol.com.br/educacao/2017/12/1944963pais-tem-118-milhoes-de-analfabetos-taxa-entre-negros-dobra-ante-brancos.shtml. Acesso em 21.12.2017.
}

Revista de Direito Brasileira | São Paulo, SP | v. 19 | n. 8 | p. 276 - 297 |Jan./Abr. 2018 
marginalizados. Da mesma forma, poucos ou nenhum foram os trabalhos envolvendo as crianças e adultos com deficiência, os transexuais e os homossexuais.

No Quadro 3há uma série de trabalhos que fazem uso da terminologia ações afirmativas, mas se referem, efetivamente, à políticas públicas sociais. Isso porque estamos considerando que o elemento chave de uma ação afirmativa é a sua compensação histórica como o principal argumento a ser empregado.

Podemos concluir, pois, que a produção jurídica, em nível de pós-graduação stricto sensu em nosso país foi pródiga no referido período; no entanto, a ausência do aprofundamento da análise dos fundamentos jurídicos que autorizaram a sua implantação em outros países, o menor aprofundamento de alguns trabalhos para a conformação de uma teoria geral das ações afirmativas, e a ausência de pesquisa e de produção de alguns grupos historicamente excluídos em nosso país são indicativos, data máxima vênia aos que entendem de forma contrária, da necessidade e um aprimoramento, e o traçado de novos horizontes a serem alcançados futuramente pela academia.

O fato é que as políticas positivas de combate à discriminação e de normalização das igualdades mostram-se cada vez mais necessárias, e elas devem ser implantadas paralelamente às políticas de universalização das políticas públicas de garantia das liberdades e da efetivação das políticas de direitos sociais.

Como bem salientado pelo Ministro Celso de Mello, quando do julgamento do ADC $\mathrm{n}^{\circ}$ 41, "sem se reconhecer a realidade de que a Constituição impõe ao Estado o dever de atribuir a todos os que se situam à margem do sistema de conquistas em nosso país a condição essencial de titulares do direito de serem reconhecidos como pessoas investidas de dignidade e merecedoras do respeito social, não se tornará possível construir a igualdade nem realizar a edificação de uma sociedade justa, fraterna e solidária, frustrando assim um dos objetivos fundamentais da República, a que alude o inciso I do artigo $3^{\circ}$ da Carta Política”.

O fato é que não há como se negar que os cursos de pós-graduação em Direito de nosso país estão a participar da evolução desse processo de realização de uma política real de igualdade. A academia, no entanto, deve continuar no acompanhamento da execução e da busca pela efetividade das políticas de discriminação positiva que foram iniciadas e hão de contribuir ainda mais para o seu aperfeiçoamento jurídico e prático. Oxalá possamos, ainda nesse século, reduzir as diferenças sociais e econômicas a afastar,num futuro próximo,a necessidade de outras ações afirmativas.

\section{REFERÊNCIAS BIBLIOGRÁFICAS}

ALEXY, Robert. Teoria dos direitos fundamentais. Tradução de Virgílio Afonso da Silva. São Paulo: Malheiros Editores, 2015.

ANSELMO, José Roberto. As ações afirmativas.In: ARAUJO, Luiz Alberto David (Coord.). Efetivando direitos constitucionais. Bauru: Edite, 2003, p. 131 a 142.

BOBBIO, Norberto. A era dos direitos. Rio de Janeiro: Campus, 1992.

BONAVIDES, Paulo. Curso de direito constitucional. São Paulo: Malheiros, 2008.

BRANCALEON, Brigida Batista et al.Políticas Públicas: Conceitos Básicos. USP: São Paulo, 2015.

BUCCI, Maria Paula Dallari. Fundamentos para uma teoria jurídica das políticas públicas. São Paulo: Saraiva, 2013. 
CANOtilHO, J.J. Gomes. Direito Constitucional e Teoria da Constituição. Coimbra: Almedina, 2002.

CARVALHO NETO, Tarcísio Vieira de. O princípio da impessoalidade nas decisões administrativas. Brasília: Gazeta Jurídica, 2015.

COMPARATO, Fábio Konder. A afirmação histórica dos direitos humanos. São Paulo: Saraiva, 2001.

DUARTE, A. C. A Constitucionalidade das Políticas de Ações Afirmativas. Brasília: Núcleo de Estudos e Pesquisas/CONLEG/Senado, abril/2014 (Texto para Discussão no 147). Disponível em: www.senado.leg.br/estudos. Acesso em 15.12.2017.

DWORKIN, Ronald. Freedom's Law: the Moral reading of the American Constitution. Cambridge: Harvard University Press, 1996.

FERREIRA FILHO, Manoel Gonçalves. Aspectos jurídicos das ações afirmativas. Revista do Tribunal Superior do Trabalho, Porto Alegre, RS, v. 69, n. 2, p. 72-79, jul./dez. 2003.

GARCIA, P. G. Análise das ações afirmativas à luz do princípio da igualdade.Jus.com.br., fev. 2012. Disponível em: https://jus.com.br/artigos/21152/analise-das-acoes-afirmativas-a-luz-doprincipio-da-igualdade/1. Acesso em 18.12.2017.

GOMES, Joaquim B. Barbosa. Ação Afirmativa e Princípio Constitucional da Igualdade. Rio de Janeiro: Renovar, 2001.

GOMES, Joaquim B. Barbosa; SILVA, Fernanda D. L. L. da. As ações afirmativas e os processos de promoção da igualdade efetiva.In: SEMINÁRIO INTERNACIONAL AS MINORIAS E O DIREITO, 2001. Brasília. Conselho da Justiça Federal, Centro de Estudos Judiciários; AJUFE; Fundação Pedro Jorge de Mello e Silva; The Britsh Council.-Brasília, (Série Cadernos do CEJ, v.24).Disponível em:<http://www.cjf.jus.br/revista/seriecadernos/vol24/artigo04/expediente.pdf> Acesso em 14.12.2017.

JELLINEK, Georg. Teoría General Del Estado. México: Fondo de Cultura Econômica, 2000.

KIM, Richard Pae. Separação de poderes e as teorias interna e externa dos direitos fundamentais: direitos sociais e a inaplicabilidade da teoria externa. Revista de Direito Brasileira, v. 10, n. 5, 2015, p. 273 a $301 . \quad$ Disponível também em: http://www.rdb.org.br/ojs/index.php/rdb/article/view/347.

KIM, Richard Pae. Titularidade dos direitos fundamentais difusos e coletivos. In:KIM, Richard Pae; BARROS, Sergio Resende de; KOSAKA, Fausto Kozo Matsumoto (Coords.) Direitos fundamentais difusos e coletivos: questões sobre a fundamentalidade. São Paulo: Verbatim, 2012.

MELlo, Celso Antônio Bandeira. O Conteúdo Jurídico do Princípio da Igualdade. São Paulo: Malheiros, 2011.

MENDES, Gilmar Ferreira; COELHO, Inocêncio Mártires; BRANCO, Paulo Gustavo Gonet. Hermenêutica constitucional e direitos fundamentais. Brasília: Brasília Jurídica,2002. 
MENDES, Gilmar; BRANCO, Paulo Gustavo Gonet. Curso de Direito Constitucional. São Paulo: Saraiva, 2013.

MÜLLER, Friedrich.Métodos de Trabalho do Direito Constitucional. São Paulo: Max Limonad, 2000.

PIOVESAN, Flávia. Ações afirmativas da perspectiva dos direitos humanos. Cadernos de Pesquisa, São Paulo, v. 35, n. 124, p. 43-55, jan./abr. 2005.

Plataforma Sucupira, referência em 2016: Disponível em https://sucupira.capes.gov.br/sucupira/public/consultas/coleta/programa/quantitativos/quantitativ oAreaAvaliacao.jsf;jsessionid=IpC19tcuSCVdbQWNHKsjYjWE.sucupira-213. Acesso em 21.12.2017.

RIVERO, Jean \& MOUTOUH HUGUES. Liberdades Públicas I. São Paulo: Martins Fontes, 2009.

ROCHA, Cármen Lúcia Antunes. Ação afirmativa - o Conteúdo Democrático do Princípio da Igualdade Jurídica. Revista Trimestral de Direito Público, São Paulo, v. 15, p. 85-99. 1996.

ROMANOWSKI, Joana Paulin; ENS, Romilda Teodora. As Pesquisas Denominadas do Tipo 'Estado da Arte' em Educação. Revista Diálogo Educacional, v. 6, n. 19, p. 37-50. 2006.

SARLET, Ingo Wolfgang. Dignidade da pessoa humana e direitos fundamentais. Porto Alegre: Livraria do Advogado, 2008.

SARMENTO, Daniel. Por um constitucionalismo inclusivo: História Constitucional Brasileira, Teoria da Constituição e Direitos Fundamentais. Rio de Janeiro: Lumen Juris, 2010.

SILVA, José Afonso da. Curso de Direito Constitucional Positivo. São Paulo: Malheiros, 2016.

SILVA, Josenilton; JACCOUD, Luciana; SOARES, Sergei; SILVA, Waldemir. A promoção da igualdade racial no primeiro semestre de 2007 e os programas de ação afirmativa nas universidades públicas. In: JACCOUD, Luciana (Org.). A Construção de uma Política de Promoção da Igualdade Racial: uma análise dos últimos 20 anos. Brasília: Ipea, 2009, p. 171 204.

SILVA, Sidney Pessoa Madruga da. Discriminação positiva: ações afirmativas na realidade brasileira. Brasília: Brasília Jurídica, 2005.

TORRES, Álvaro Luiz Palacios. Ações afirmativas e limites às políticas públicas de igualdade.Dissertação (Mestrado em Direito)-Universidade Metodista de Piracicaba, Piracicaba, 2012. 